\title{
The Politicization of European Integration: National Parliaments and the Democratic Disconnect ${ }^{1}$
}

\author{
Richard Bellamy1 and Sandra Kröger 2
}

1. Max Weber Programme, European University Institute, Via dei Roccettini, 9, 50014 San Domenico di Fiesole (FI), Italy e.mail: richard.bellamy@eui.eu

2. Department of Politics, University of Exeter, Amory, Rennes Drive, Exeter, EX4 4RJ, UK. E-mail: $\underline{\text { S.Kroeger@exeter.ac.uk }}$

Discussion of the democratic strengths or, more usually, weaknesses of the EU tends to focus on the degree of democracy that is available or possible at the EU level. Such thinking reflects a certain neo-functionalist logic that has governed much scholarly writing about the relationship between EU integration and democracy. It assumes that enhanced competences for EU institutions potentially create a democratic deficit at the European level that can only be filled by enhancing to an equal degree the democratic features of those same bodies, most especially by increasing the powers of the European Parliament (EP) (Rittberger 2005; 2014). The articles in this special issue take a different tack that challenges that assumption. They focus on what has been called the democratic disconnect between the domestic democratic institutions of the member states and the EU (Lindseth 2010: 234), rather than a democratic deficit in the operation of EU institutions. Consequently, the contributors look at how EU policy-making might be authorized by, and rendered more responsive and accountable to, the citizens of the member states through EU affairs and policy-making figuring more prominently in their domestic democratic processes, with National Parliaments (NPs) playing a key role as mechanisms of democratic reconnection.

The circumstances creating both the need and the possibility for such a democratic reconnection have arisen with the growing politicization of EU affairs at the domestic level that has come with the Euro crisis. Politicisation in this context involves greater issue salience, actor expansion, and polarization (Hutter and Grande 2014), stemming from the increased political authority of the EU, the rising prominence of and voter interest in the issues it tackles as a result of its enhanced competences (de Wilde and Zürn 2012), and the ways it appears to undermine or constrain domestic democratic decision-making (Schmidt 2006). The degree and nature of politicization depends on the existence of a favourable 
political opportunity structure, defined as national narratives, media receptiveness, competitive party politics, referendums and crises. Such politicization has been categorised along three dimensions (see Hurrelmann 2012). First, it may occur in different discursive arenas (parliaments, parties, civil society, media, citizens). Second, it may address different aspects of European integration (constitutional issues, identities, concrete policies). Third, it relates to different kinds of political cleavages (national structures of conflict and transnational structures of conflict). However, while some scholars have assumed that such politicisation offers an opportunity to develop democracy at the EU level, most particularly through the development of European political parties and the strengthening of the EU (de Wilde and Zürn 2012), our focus lies in exploring its potential for fostering democracy with regard to the EU at the member state level.

We will here define politicization as follows: a European issue is politicized to the extent it is raised as a relevant object of - or factor in - political contestation within the main arenas of collective decision-making of a domestic political system. In other words, politicization denotes the saliency of and polarization around a European issue in domestic political discourse. There can be no doubting that politicization in this sense has occurred to an ever greater degree in recent years (Hutter and Grande 2014; Kriesi and Grande 2012; Miklin 2014; De Wilde and Zürn 2012) though some commentators remain cautious as to the degree to which domestic public spheres have been politicized (Hurrelmann, Gora and Wagner 2014; Miklin 2014). Crisis-related decisions, like those to provide financial support to Greece, or measures like the European stability mechanism or the Fiscal Compact, have caused wide debate and media attention, and resulted in public protest in many member states. Eurobarometer data from autumn 2012 reveals that awareness of EU institutions has reached an all-time high (91\% of respondents having heard of the EP, $85 \%$ of the Commission and ECB, $71 \%$ of the Council) (Standard Eurobarometer 78, Public Opinion in the EU - Autumn 2012).

Such politicization at the domestic level can involve either hostility to the integration process, as in the case of the rise of populist Eurosceptic movements, or the assimilation of EU affairs into mainstream political debate by the main government and opposition parties. To adapt Hurrelmann's (2012) categorization, the first kind of politicization relates to constitutional and identity issues and involves a cleavage between pro- and anti- EU, whereas the second concerns predominantly concrete policies and involves a cleavage between left and right that entails a debate about which kind of EU to have rather than whether the EU should 
exist at all. Many commentators have regarded the domestic politicization of the EU as naturally tending towards the former, Eurosceptic, rather than the latter, left-right, variety (Bartolini 2005; Mudde 2013). For example, Hooghe and Marks (2009) characterise politicization of the EU as operating primarily along a 'GAL-TAN' dimension, with green/alternative/libertarian parties arguing for, and traditional/authoritarian/nationalist parties arguing against further (or even any) integration. From this perspective, the politicization of EU affairs becomes associated with waning support for the EU and raises fears of a backlash and increasing gridlock in EU decision-making, as member state governments increasingly insist on protecting narrowly defined national interests to appease growing Eurosceptic demands. Yet, arguably such attitudes derive from the failure of the main parties to politicize EU issues themselves. As Hooghe and Marks (2009) also note, 19 of the most mainstream European political parties are more Euro-supportive than their voters, and often internally divided among their members over the issue, with the result that they have attempted to depoliticize the issue. However, it might be that this failed strategy was misguided, and that if they became mechanisms of politicization of EU affairs instead, then they could strengthen European democracy and contribute to weakening the lack of congruence in the EU system of multilevel governance between where decisions are made (in Brussels) and where politics plays itself out (in the national capitals) (Schmidt 2006). However, to achieve such a democratic reconnection, the nature of politicization needs to be moved from simply debating the legitimacy of more or less (or any) EU integration and turn instead to the discussion of the desirability of different kinds of European policies. This shift will only occur if mainstream parties take the initiative and employ politicisation in ways that undercut Eurosceptic claims that the EU undermines member state democratic processes and identities.

In this special issue we explore the extent to which NPs and political parties can foster this form of politicization. With the Lisbon Treaty, NPs have acquired new powers that potentially make this process possible (Article 12 TEU). They now have the ability to ensure EU measures respect the principles of subsidiarity and proportionality (Article 5 TEU). They are also better informed, having draft legislative proposals forwarded to them directly. In addition, inter-parliamentary fora have developed that allow them to act directly at the EU level in key areas involving executive discretion, notably fiscal matters and foreign and security policy. The articles in this issue explore different facets of these powers as employed by NPs and political parties. In each case, the authors explore how far they have facilitated the domestic politicization of EU affairs by the main national political parties. 
The text by Sandra Kröger and Richard Bellamy sets the scene by exploring the normative and empirical basis for NPs to act as mechanisms for what they term the domestication and the normalization of EU affairs. Domestication involves both the 'taming' of the EU, so that it respects the integrity of the domestic democratic sphere, through such measures as the policing of subsidiarity, and the 'bringing home' of EU affairs by facilitating its domestic debate. Normalization involves the framing of the debate in ideological terms, such as left-right, with regard to concrete policies. The argument is that taming the EU potentially allows it to be brought home and debated in normalized terms. Other contributions pick up this theme. Katrin Auel, Olga Eisele and Lucy Kinski explore how far the electoral contestation of EU issues as a result of the Euro crisis has created an incentive structure that promotes communication of EU affairs by parties. Their data, collected in seven EU parliaments from 2010 to 2013, shows that greater political contestation in public opinion has a positive impact on the communication of EU affairs. However, it also reveals that the impact of political contestation within parliament is ambivalent in that the presence and strength of Eurosceptic parties is a positive, but surprisingly not a decisive, factor for parliamentary communication, while disagreement between the governing parties decreases the overall number of communication activities'. By contrast, the article by Tapio Raunio looks at the ways the representation of the Eurosceptic True Finns in the Finnish parliament has potentially undermined established norms of appropriateness of how to deal with EU affairs in the Eduskunta. Given NPs are most effective at debating and influencing policy to the extent at least a majority of their members share a broad agreement on the legitimacy and even obligation of their deliberating given issues, domestic politicization based on a pro-anti EU cleavage may undermine the capacity for the parliamentary domestication and normalization of EU affairs. However, the contribution by Arndt Wonka and Sascha Göbel reveals how in more propitious conditions parliaments may be able to achieve both these effects. Germany benefits from a low level of Euroscepticism and the advantage of being the dominant player in the EU, a position much strengthened by the Euro crisis, even if that status brings considerable obligations as well as advantages. In addition, the NP, the Bundestag, is a strong parliament, the position of which in EU matters has been considerably strengthened by the Federal Constitutional Court. As a result, the authors find that considerable left-right contestation could occur over the fiscal measures adopted during the Fiscal Crisis without calling into question Germany's support for the EU. 
The last two contributions explore the inter-parliamentary role of NPs. The text by Carina Sprungk notes that NPs today seem to be ascribed mainly coordinative roles in the EU, and that their de facto cooperation may work against the politicization of EU affairs as defined above. According to Sprungk, that is because the object of their contestation is the EU itself, as well as the behaviour of the domestic government, rather than substantive issues, thereby preventing a more partisan debate of EU affairs. Finally, the contribution by Ian Cooper, which addresses the recently created inter-parliamentary conference to discuss and oversee the EU's regime of economic governance (Article 13 of the Fiscal Treaty), confirms two main aspects of NPs' involvement in EU affairs. First, it shows that NPs have started to exert a collective role in the oversight of EU legislation, thereby seeking to assert a stronger role overall. And second, it shows that NPs still seem not to debate EU affairs mainly in terms of left-right or associated ideological cleavages, confirming the argument made by Sprungk as well as by Kröger and Bellamy. Instead, the debates so far have focused on the 'nature and purpose of the conference itself', reflecting 'competing visions for the parliamentary oversight of the EU' between the EP and NPs. Nevertheless, the attempt by the latter to strengthen their role through such inter-parliamentary bodies testifies to a concerted wish on the part of NPs to domesticate and tame the EU and to thereby address the democratic disconnect.

Therefore, the evidence is mixed as to how far NPs can redirect the politicization of the EU in ways that will promote democratic reconnection and thereby subvert Eurosceptic opposition to regional integration. Much depends on contingent factors, such as the strength and weakness of the member states, the role of the NPs in the political system, the tradition of populist opposition to the EU and party politics more generally, and the ways these interact. It may also be that inter-parliamentary cooperation serves to Europeanize parliaments in ways that subvert their domestic role as forums for contestation, control and communication of executive action. Yet, it is also true that NPs are reasserting their rights and in the process changing the character of EU decision-making in ways that reflect the reassertion of the need to reflect, respond and reconnect to the ever more politicised democratic will of the electorates of the member states.

\section{References}


Bartolini, S. (2005) Restructuring Europe: centre formation, system building and political structuring between the nation state and European integration (Oxford: Oxford University Press).

Closa, C. and Maatsch, A. (2014) 'In a Spirit of Solidarity? Justifying the European Financial Stability Facility (EFSF) in National Parliamentary Debates', Journal of Common Market Studies, 52:4, 826-842.

Hass, E. (1958) The Uniting of Europe (Palo Alto, Calif.: Stanford University Press).

Hooghe, L. and Marks, G. (2009) 'A postfunctionalist theory of European integration: from permissive Consensus to constraining dissensus', British Journal of Political Science, 39:1, 123.

Hurrelmann, A. (2012) Will the Eurozone Crisis Lead to a Politicization of European Integration? Mini-paper prepared for the conference "The Euro Crisis and the Future of the EU”, Syracuse University, 21-22 September 2012.

Hurrelmann, A., Gora, A. and Wagner, A. (2013) 'The Politicization of European Integration: More than an Elite Affair?' Political Studies, doi: 10.1111/1467-9248.12090.

Hutter, S. and Grande, E. (2014) 'Politicizing Europe in the National Electoral Arena: A Comparative Analysis of Five West European Countries, 1970-2010', Journal of Common Market Studies, 52:5, 1002-1018.

Hutter, S. and Kerscher, A. (2014) 'Politicizing Europe in Hard Times: Conflicts over Europe in France in a Long-Term Perspective 1974-2012', Journal of European Integration, 36:3, 267-282.

Kriesi, H. and Grande, E. (2012) 'The Euro-Crisis: A Boost to Politicization of European Integration?' Paper presented at the EUDO Dissemination Conference on the Euro Crisis and the State of European Democracy, Florence, 22-23 November.

Lindseth, P. (2010) Power and Legitimacy: Reconciling Europe and the Nation State (Oxford: Oxford University Press).

Matthijs, M. (2014) 'Mediterranean Blues: The Crisis in Southern Europe', Journal of Democracy, 25:1, 101-115.

Miklin, E. (2014) 'EU Politicisation and National Parliaments: Visibility of Choices and Better Aligned Ministers?', The Journal of Legislative Studies, 20:1, 78-92.

Moravcsik, A. (2008) 'The Myth of Europe's "Democratic Deficit”, Intereconomics, 331340 .

Mudde, C. (2013) "Thirty Years of Populist Radical Right Politics in Western Europe: So What? The 2012 Stein Rokkan Lecture”, European Journal of Political Research, 52.1, 1-19.

Risse, T. (2005) 'Neofunctionalism, European Identity and the Puzzles of European 
Integration', Journal of European Public Policy, 12:2, 291-309.

Rittberger, Berthold (2005) Building Europe's Parliament. Democratic Representation Beyond the Nation State, (Oxford: Oxford University Press)

Rittberger, Berthold (2014) 'Integration without Representation? The European Parliament and the Reform of Economic Governance in the EU', Journal of Common Market Studies, 52, 6: $1174-1183$

Schmidt, V. A. (2006) Democracy in Europe: The EU and National Polities (Oxford: Oxford University Press).

Wendler, F. (2014) 'Justification and political polarization in national parliamentary debates on EU treaty reform', Journal of European Public Policy, 21:4, 549-567.

de Wilde, P. and Zürn, M. (2012) 'Can the politicization of European integration be reversed?' Journal of Common Market Studies, 50:1, 139-153.

\footnotetext{
${ }^{1}$ We are grateful to the Hanse-Wissenschaftskolleg in Delmenhorst for providing us with Research Fellowships for 2013-14 and funding the workshop at which the papers for this special issue were first presented.
} 